\title{
Fuel Options for Bangladesh-2017
}

\author{
Engr Sk Shafi Ahmed \\ Ex CEO, KAFCO Plant, P.Engg and Fellow IEB
}

\begin{abstract}
Fuel is an essential commody supporting our daily life and economy. Until today, the majority of Bangladesh fuel is met from domestic natural gas production. With economy growing (like GDP $7^{+} \%$ ) in coming years, fuel use is also increasing and the local gas prodcution could not meet the requirement. Goverment has already taken steps for the import of LNG and LPG to support the shortfall. This paper describes different fuel options and suggests that the additional fuel requirement might be met with the imported LNG considering the environmental and cost of fuel. LPG is costly than imported LNG. So, emphasis on LPG use may be considered only to the areas where there is no pipe gas supply.
\end{abstract}

Keywords: Fuel Options, LPG, LNG, Natural Gas, Electricity

\section{Introduction}

Fuel is a daily essential commodity of our life. In Bangladesh, Natural gas is the prime fuel used for domestic cooking, transport, electricity, fertilizer production, other commercial and industries. The use of natural gas in this county started since 1960today about $70 \%$ of the fuel need is met through natural gas (except bio mass). About $2700 \mathrm{mmscf}$ is produced and distributed daily around greater Dhaka, Chittagong, Camilla, Noakhali, Bhola and Sylhet.The countries north and south regions are almost without natural gas supply, except a few places. The present gas shortage has been estimated about $500 \mathrm{mmscf}$ daily. Some industries like fertilizer plants operate only several months for shortage of natural gas. The gas supply to the domestic cooking is also stopped.

As an alternative, use of LPG (liquefied Petroleum gas) is being encouraged. The countries (Eastern Refinery) yearly LPG production is only 20 thousand MT while the import amount is about 300 thousand metric ton from international market supply. The majority LPG use is restricted to domestic and commercial cooking and the use is being encouraged. The advocacy for the use of LPG is that piped natural gas supply is costly.

Importing natural gas as LNG is costly. A separate, dedicated safety terminal is required. The natural gas temperature is reduced down to minus $162^{\circ} \mathrm{C}$ in order to liquefy it. Then, the liquid natural gas is shipped to the special jetty. It is unloaded, regasified and pressurized for the supply. The transport and supply cost of LNG is 3 to 4 times than its gas purchase cost.

The proven reserve of the country natural gas is 1012 trillion cubic feet .About 1 trillion cubic feet is being used every year. If further new gas fields are not discovered, the present gas reservoir will deplete within a decade. It is estimated that more than 8000 mmsfd natural gas will require to keep the economy up by the year 2030. This is about 3 trillion cubic feet yearly. So, imported LNG and LPG will play a strong role in the future energy requirement in Bangladesh.

Petrol, Kerosene, Diesel, and furnace oil are being used as a liquid fuel. But its use is decreasing because of high cost and detrimental environment issue .Solar energy is being practiced on a limited scale to meet the domestic light use in rural Bangladesh.

Wood, dried leaf, rice husk are still the major cooking fuel in many villages, districts and Thana/upozelas in Bangladesh.

The good news is that enough LPG and LNG is available in the international market and the supply will continue for several decades. All the developed and developing countries in Asia like Japan, China, South Korea, India, Singapore, Pakistan, Thailand are increasingly depending on the LNG and LPG supply because of its environment and clean fuels.

The important issue is price. LNG and other fuel price fluctuates like a sinusoidal curve in the international energy market.

Fuel supply has different options in its use considering the cost, technology and its environmental effect. This paper discusses and highlights fuel use options in the country based on 2017 situation.

\section{The present Fuel supply and price in Bangladesh:}

2.1 Natural gas: Bangladesh natural gas production is from onshore mainly in the greater district of Sylhet and Camilla. It is pure and mainly $97 \%$ methane and with some higher hydrocarbon. The sulfur content is very low like $5 \mathrm{ppm}$. The natural gas is lighter than air and is very clean and 
environment friendly fuel. Natural gas is compressed to higher pressure (like $200 \mathrm{Kg} / \mathrm{cm}^{2}$ ) to supply fuel for the automobiles. It is called Compressed Natural Gas (CNG). CNG is playing a very big role to reduce environmental pollution in the city of Dhaka and Chittagong.

Table -1: Bangladesh Natural Gas Cost -2017.

\begin{tabular}{|c|c|c|c|c|}
\hline Item & $\begin{array}{l}\text { Price } \\
\text { per } \\
\mathrm{m}^{3} \\
\text { Taka }\end{array}$ & $\begin{array}{l}\text { Equivalent } \\
\text { US } \$ / \mathrm{m}^{3} \\
\{80 \mathrm{Tk}-1 \\
\text { US } \$\}\end{array}$ & $\begin{array}{l}\text { Us } \$ \\
\text { per } \\
\text { mcf }\end{array}$ & $\begin{array}{l}\% \text { of } \\
\text { Total }\end{array}$ \\
\hline Electricity & 3.16 & 0.0395 & 1.118 & 40.37 \\
\hline $\begin{array}{l}\text { Captive } \\
\text { Power }\end{array}$ & 9.62 & 0.1202 & 3.40 & 17.19 \\
\hline Fertilizer* & 2.71 & 0.0338 & 0.957 & 7.10 \\
\hline Industry & 7.76 & 0.097 & 2.74 & \\
\hline Tea Garden & 7.42 & 0.0927 & 2.62 & 17.19 \\
\hline Commercial & 17.04 & 0.213 & 6.032 & \\
\hline $\begin{array}{l}\mathrm{CNG}^{* *} \\
\text { Household }\end{array}$ & 40.0 & 0.5 & 14.16 & $\begin{array}{l}5.04 \\
13.08\end{array}$ \\
\hline One burner & $\begin{array}{l}750 \\
\text { fixed }\end{array}$ & 9.375 & & \\
\hline Two burner & $\begin{array}{l}800 \\
\text { fixed }\end{array}$ & 10 & $5.34^{* * *}$ & \\
\hline $\begin{array}{l}\text { Meter } \\
\text { based }\end{array}$ & 11.20 & 0.14 & 3.96 & \\
\hline
\end{tabular}

Total consumption as of 2017-2650 mmscfd

Source: Titas Gas

*KAFCO pays a formula gas rate on urea selling price

** Taka 8 per $\mathrm{m}^{3}$ operator rate is included(2.83 US\$ per mcf)

$* * *$ Estimated based on avg family consumption of $66 \mathrm{~m}^{3}$ (design being $88 \mathrm{~m}^{3}$ )

The Table-1 shows the following:

- The lowest gas price is for Fertilizer, Tk 76.56 per mcf and consumes only about $8 \%$

- Gas price for electricity generation is also low, Tk 89.44 per mcf(except captive). It consumes bulk gas about $58 \%$.

- Transport sector pays the highest gas price Tk 1132 per $\operatorname{mcf}(14.16$ US \$ per mcf). Transport sector consumes only $5 \%$

- Household cooking has two types(a) meter based Tk 316 per mcf and (b) fixed rate Tk 427 per mcf. It consumes $13 \%$.

- The average gas price is Tk 240 per mcf( US $\$ 3$ per mcf)

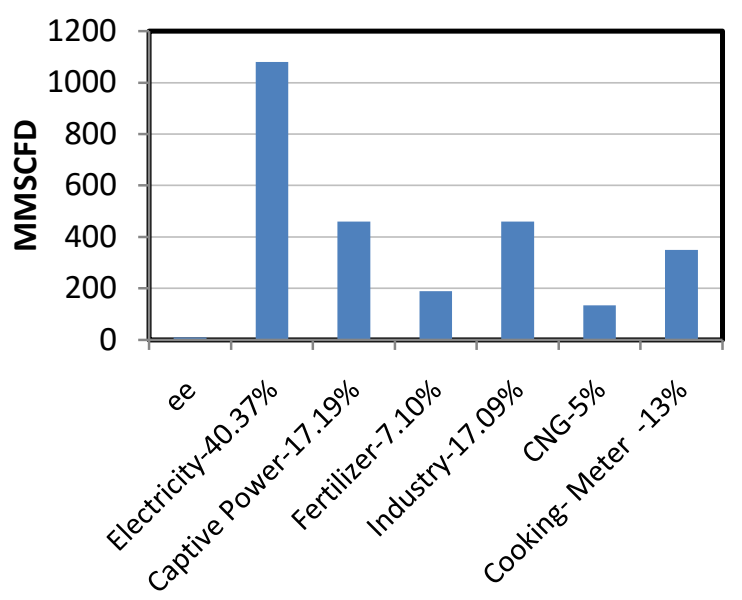

Fig-1: Daily gas consumptions in different sectors

\section{2: LPG (Liquid Petroleum Gas):}

LPG is composed of a mixture of Propane $\left(\mathrm{C}_{3} \mathrm{H}_{8}\right)$ and Butane $\left(\mathrm{C}_{4} \mathrm{H}_{10}\right)$. Mostly it is a byproduct from Petroleum refinery .LPG is also processed from natural gas. Like natural gas, it is also a clean fuel and environmental friendly. It is heavier than air.LPG is mostly used for domestic cooking and auto gas. In Bangladesh, LPG is mostly used for cooking and the majority is imported $.1 \mathrm{Kg} \mathrm{LPG}$ has $0.5 \mathrm{~m}^{3}$ gas.

LPG is found in all main cities of Bangladesh especially in the north and south where Natural gas has not been supplied through pipes. The import and supply is mainly in the hand of private companies.

Table -2: Bangladesh LPG Cost -2017

\begin{tabular}{|c|c|c|c|c|}
\hline Organization & $\begin{array}{c}\text { LPG } \\
\text { Bottle } \\
\text { Size, } \mathrm{Kg}\end{array}$ & $\begin{array}{l}\text { Price, } \\
\text { Taka }\end{array}$ & $\begin{array}{c}\text { Price } \\
\text { Tk } \\
\text { per } \\
\mathrm{Kg}\end{array}$ & $\begin{array}{c}\text { US \$ } \\
\text { per } \\
\mathrm{Kg}\end{array}$ \\
\hline \multicolumn{5}{|l|}{ Bangladesh } \\
\hline $\begin{array}{l}\text { Corporation } \\
\text { (BPC) }\end{array}$ & 12.5 & 700 & 56 & 0.70 \\
\hline Bashundhara & 12 & $\begin{array}{r}* 900- \\
1100\end{array}$ & $75-92$ & $\begin{array}{c}0.93- \\
1.15\end{array}$ \\
\hline Jamuna] & 35 & $\begin{array}{l}{ }^{*} 2300- \\
2700\end{array}$ & $65-77$ & $\begin{array}{l}0.81- \\
0.96\end{array}$ \\
\hline Omera & 5 & 500 & 100 & 1.25 \\
\hline
\end{tabular}

* Variation of price is different in different citymainly because of the transportation cost

The Table-2 shows the following: For domestic Cooking

- The government supply (BPC) is the lowest cost 56 Taka per $\mathrm{Kg}$. BPC uses $12.5 \mathrm{Kg}$ supply but it is very limited. 
- Private companies uses $12 \mathrm{~kg}$ cylinder as domestic cooking supply and the cost vary from Tk 75 to 92 depending on locations

- The cost of LPG in big capacity cylinders $(35 \mathrm{~kg})$ is lower and it is mostly used in hotels and commercial.

2.3 Petrol, Octane. Kerosene, Diesel and Furnace oil:

Table -3: Bangladesh Liquid Fuel Cost-2017

\begin{tabular}{lcccc}
\hline Item & $\begin{array}{l}\text { Tk } \\
\text { /liter }\end{array}$ & $\begin{array}{l}\text { US\$/ } \\
\text { liter }\end{array}$ & $\begin{array}{c}\text { Consumption, Quantity in } \\
\text { MT }\end{array}$ \\
\hline & & & $2015-16$ & $2016-17$ \\
\cline { 4 - 5 } Jet A1 & & & 347323 & 376700 \\
Octane & 89 & 1.11 & 147557 & 186911 \\
Petrol & 85 & 1.06 & 137360 & 232359 \\
Diesel & 65 & 0.81 & 3606404 & 4000044 \\
Kerosene & 65 & 0.81 & 213685 & 170993 \\
Furnace oil & 42 & 0.52 & 711889 & 806440 \\
\hline
\end{tabular}

Source: BPC website

\subsection{Electricity:}

Table -4: Bangladesh Electricity Cost for different customers-2017

\begin{tabular}{lcc}
\hline Category A ; Residential & $\begin{array}{c}\text { Unit Rate } \\
\text { Taka }\end{array}$ & US\$ Cent \\
\hline 1st Step: From 1 to 75 units & 3.80 & 4.75 \\
2nd Step: From 76 to 200 units & 5.14 & 6.42 \\
$\begin{array}{l}\text { 3rd Step: From } 201 \text { to } 300 \\
\text { units }\end{array}$ & 5.36 & 6.7 \\
$\begin{array}{l}\text { 4th Step: From } 301 \text { to } 400 \\
\text { units }\end{array}$ & 5.63 & 7.03 \\
$\begin{array}{l}\text { 5th Step: From } 401 \text { to } 600 \\
\text { units }\end{array}$ & 8.70 & 10.87 \\
$\begin{array}{l}\text { 6th Step: From 600 units and } \\
\text { above }\end{array}$ & 9.98 & 12.47 \\
\hline Category-B Agriculture pumping & & \\
\hline $\begin{array}{l}\text { Agriculture pumping } \\
\text { Category C: Small Industries }\end{array}$ & 3.82 & 4.77 \\
$\begin{array}{l}\text { a. Flat rate } \\
\text { b. Off peak time }\end{array}$ & 7.66 & 9.57 \\
$\begin{array}{l}\text { c. Peak time } \\
\text { Category D: Non Residential } \\
\text { (light and Pons) }\end{array}$ & 6.90 & 8.62 \\
\hline Category E :Commercial and Office & 5.24 & 11.55 \\
\hline $\begin{array}{l}\text { a. Flat Rate } \\
\text { b. Off Peak time }\end{array}$ & 9.80 & 12.25 \\
c. Peak time & 8.45 & 10.67 \\
\hline Source: BDB website & 11.98 & 14.97 \\
\hline
\end{tabular}

Source: BDB website

\subsection{Wood, Dried leaf etc-2017:}

Wood, dried leaf and other biomass still constitute the Bangladesh a major fuel requirement (more than $50 \%$ ) and the village life depends on this type of fuel.
Table -5: Bangladesh Wood Cost per Kg -2017

\begin{tabular}{ccc}
\hline Fuel Type & $\begin{array}{c}\text { Dhaka; Tk per } \\
\mathrm{Kg}\end{array}$ & $\begin{array}{c}\text { Jessore, Tk } \\
\text { per Kg }\end{array}$ \\
\hline $\begin{array}{c}\text { Dried wood } \\
\text { Wood from rice } \\
\text { husk }\end{array}$ & $7.5 / 7$ & 5 \\
\hline
\end{tabular}

\section{Environment friendly Fuel}

The following figure shows the carbon emission for different types of fuel; Pounds of $\mathrm{CO}_{2}$ emitted per million BTU of energy

$\begin{array}{ll}\text { Coal (anthracite) } & : 228.6 \\ \text { Coal Bituminous } & : 205.7 \\ \text { Diesel } & : 161.3 \\ \text { Gasoline } & : 157.2 \\ \text { Propane } & : 139.0 \\ \text { NG } & : 117.0\end{array}$

It shows that Natural gas is the most clean producing lowest $\mathrm{CO}_{2}$. LPG is close to it. . In addition, our Natural Gas do not have S. So burning NG is generally SOx and NOx free.

\section{Comparative cost of fuels in Bangladesh-2017}

In this section we shall study the present fuel cost in Bangladesh with the same heating value.

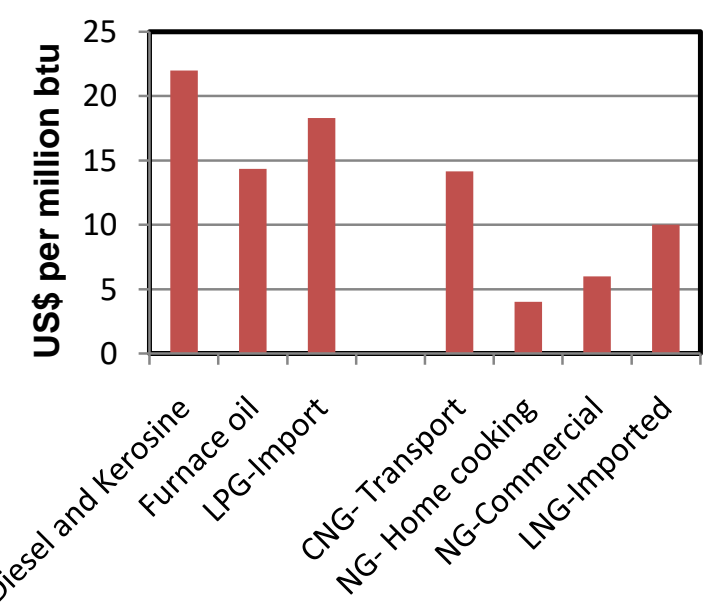

Fig-2: Cost of different fuel with same heating value (or energy value or calorific value)-2017 price

\section{Fuel International price}

The international price for the liquid natural gas varies over months and years following the price of Brent oil. Fig -3 shows that the price has varied between US $\$ 20$ to US\$10 during the five years 2010--2015. Price deal for LNG is also related to Brent oil. 
For example: Bangladesh recent deal for the LNG import from Abu Dhabi is based on the formula:

LNG Price $=12.65 \%$ * 3 months avg price of Brent oil+0.50 US \$ per mm BTU. The regasifictaion, gas transport and other FSRU cost to be added here

We have to keep in mind that the global price Fuel fluctuation has to be adjusted on a long term policy of gain and loss market.

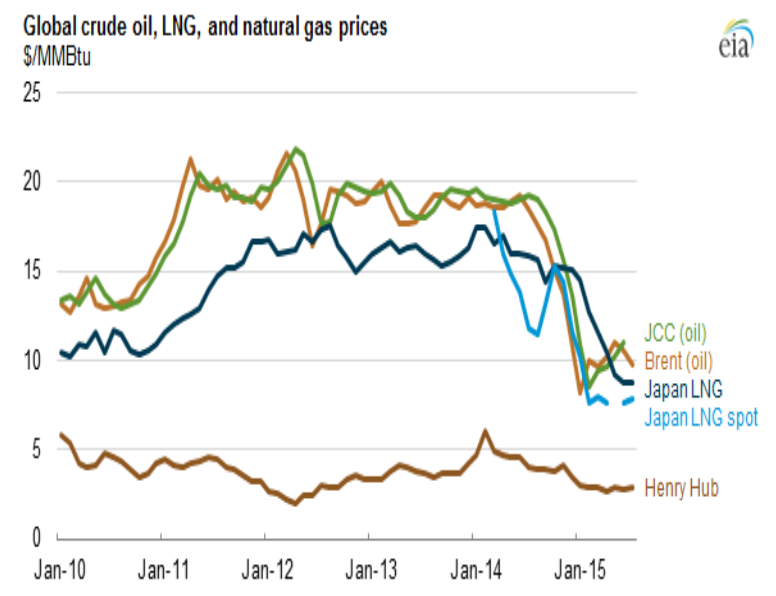

Fig-3: A scenario of global Crude oil, LNG and Natural Gas from 2010--2015

\section{Issues for Fuel use}

Fuel use by the consumers depends on factors like

- Purchasing Power

- Environment factors- avoid air and water pollution

- Price of Fuel

- Technology adapted like Efficiency of burning , Safety, Reliability and users support

- Competitiveness- Especially for electricity price

\section{LPG Use Issue: Domestic Cooking}

- The Private importers are main players for the LPG import and pricing issue. LPG is widely used in Rajshahi, Khulna, Barisal and Rangpur division, where there is no piped supply.

- At present, one medium family requires min 2 cylinders LPG costing about 2200 taka while 2 burners NG present cost 800 taka

- All fuel in Bangladesh eg. Natural gas, Diesel, Octane, Petrol, electricity are regulated and controlled by government except LPG. There is no price control and regulation for $L P G$.
- Government (BPC) is not playing a role to regulate and control LPG price and its use.

Table -6 Comparing NG and LPG cost for home cooking -2017

\begin{tabular}{|c|c|c|c|c|}
\hline & $\begin{array}{l}\text { Fixed } \\
\text { price-2 } \\
\text { burner }\end{array}$ & $\begin{array}{l}\text { Unit } \\
\text { sale } \\
\text { price }\end{array}$ & $\begin{array}{c}\text { Heat } \\
\text { value } \\
\text { per unit }\end{array}$ & $\begin{array}{c}\text { Unit } \\
\text { price } \\
\text { per MJ }\end{array}$ \\
\hline $\begin{array}{l}\text { Natural } \\
\text { Gas }\end{array}$ & Tk 800 & $\begin{array}{c}\text { Tk } \\
13.33 \\
\text { per m3 }\end{array}$ & $\begin{array}{l}39.59 \\
\mathrm{MJ} / \mathrm{m}^{*}\end{array}$ & $\begin{array}{c}\text { Tk } \\
0.336\end{array}$ \\
\hline LPG & $\begin{array}{c}\text { Tk } 1100 \\
\text { for } 12 \\
\text { Kg } \\
\text { cylinder }\end{array}$ & $\begin{array}{c}\mathrm{Tk} \\
91.66 \\
\text { per } \mathrm{Kg}\end{array}$ & $\begin{array}{l}50.80 \\
\mathrm{MJ} / \mathrm{Kg}\end{array}$ & Tk 1.80 \\
\hline \multicolumn{5}{|c|}{$\begin{array}{l}\text { The above figure shows LPG about } 5 \text { times high } \\
\text { than the present NG price }\end{array}$} \\
\hline
\end{tabular}

\section{Situation after LNG Import}

Imported LNG is a costly fuel but cheaper than imported LPG and other liquid fuels. So, what might be natural gas price after import of LNG.

The present average natural gas price of the home production is about US\$3 per mscf, where as the import price for the same amount will be 10 US\$(2017). So, there will be a mixed average gas price of home production and import- depending on the contributions. A simple estimate case is:

Local NG production: 2500 mmscfd; with avg price 3US $\$$ / MMBTU

Imported NG: 1000 mmscfd; Price 10 US \$/ MMBTU.

Total NG: 3500 mmscfd

- Price Formula $=(A v$ local price $x$ local production amount+ Import price $\mathrm{x}$ import amount )/total gas consumption(local plus import)

- So for a case of 2500 mmscfd local production with 3 US $\$$ and imported 1000 mmscfd with 10 USS per mscf , the Av mix price : $17500 / 3500=$ 5 US\$

- Now for a balancing, the Gov will decide which sector will provide lower than US\$5 and which sector higher than US\$ 5 .

The important sectors for consideration of price adjustment and gas uses are following:

Home Cooking: Now the use is $13 \%$ of the total gas usage. Present home Cooking price is about 4 US\$. The piped gas supply is in the big cities supporting millions of citizens daily cooking and life. 
CNG- Transport: Now the use is $5 \%$ of the total. The present CNG price is 14 US $\$$ per MMBTU. This price is much above the home production of average price of US\$3 mscf.

Power Generation: Now the use is $58 \%$ of the total gas consumption. It is subsidized cost is little over 1 US \$ per mscf.

Urea Fertilizer: Now the use is about $8 \%$ of the total gas usage and is subsidized. The price is 0.957 US \$ per mscf and is the lowest among all users .Bangladesh requires about $2.5 \mathrm{M}$ ton Urea annually to support its food security -- This is corresponding to $200 \mathrm{mmscfd} \mathrm{NG}$

Industry: Its present price is US\$2.74 US\$ per mscf and sure to be increased when the mixed natural gas will come.

\section{Conclusion}

Bangladesh domestic natural gas supply is not enough to meet the requirement of economic growth. So, Import is the only option. On the other hand, Bangladesh is a high populous country. The present population density of Bangladesh is around 1,252 people per square kilometer of land and the Dhaka city has a population density is about 45,000 per square kilometer. The neighboring big Indian economic city of Calcutta has a population density of only 24,000 per square kilometer. So, our choice of fuel must meet the requirement of a good air quality to support life of millions.

LNG import is costly but Natural gas (through LNG) is cheaper compare with LPG, Diesel, Furnace oils and Octane. Its environmental treatment is also minimum- in fact is not required.

Considering price, environment and user-friendly, the better option is maximizing the use of natural gas in all sectors -- by mixing home Natural gas with imported LNG. The following sectors are very important:

- Home Cooking: The piped natural gas supply should be maintained in cities for home cooking with reasonable price ( a no profit and no subsidy option). The gas supply to houses should be metered to reduce the usage. For areas, where there is no pipe supply, LPG is an option but its price should have a regulation and control.

- CNG Vehicles: At present there is no subsidy and instead Gov receives some additional money. So, the supply should be maintained. However, the price increase -if any - should be below the cost of LPG or other liquid fuel eg Diesel and Petrol.
- Electric Cars: To reduce air pollution in the Dhaka city, the electric 3 wheelers (auto rickshaw) and electric cars should be encouraged and allowed to operate.

- Urea Production: For food security, Urea Fertilizer Plants within the country should continue operation with a guaranteed supply of natural gas at a reasonable gas price (like US\$ 3 per MMBTU or less). Fertilizer Plants operation should also include measures to optimize the gas usage implementing plant reliability programs. However the fertilizer sector will require some subsidy.

- Electricity Generation and cost: Electricity generation is the biggest NG consumption area - at present about $58 \%$ of the total and this amount is increasing in coming years. Maintaining reasonable electricity cost is very important to support export economy. Millions of people are employed here especially the garments and other labour intensive sectorswhere electricity is one of the major prime mover. Bangladesh electricity cost is already about 8 cents. For the competiveness with the neighbour countries like India, Vietnam, Pakistan and Chin, the electricity price to the customers should be around 8-10 cent kWh to survive the labour intensive industry and export. Fuel pricing and subsidy -if any should match to it.

- Energy Efficiency: The energy utilization efficiencies of Bangladesh industries is low and should be improved with Plant reliability programmes to reduce the national energy consumption as well as improve air pollution levels.

- Fuel Price Fluctuation: LNG and LPG price fluctuates like sine waves in international market (varying from 8 to $20^{+}$US $\$$ per MMBTU).However, customer requires a yearly constant fuel price. So, a mechanism should be established for a financial funding support.

\section{References}

1. National Seminar on Energy Security for Bangladesh- Challenges and opportunities; BUET, Dhaka, May 28-2016

2. BPC website-annual reports

3. Bangladesh Energy Regulatory board web site

4. Power Development Board website

5. Petro bangla website

6. Internet information

7. Energy related papers in daily Prothom alo 